\title{
A Study of The Density of Motor Vehicles in Front of Bunda Hospital Margonda Depok Against Noise Pollution
}

\author{
Syaiful Syaiful, Noor Wahid \\ Civil Engineering Departement, Ibn Khaldun University, Bogor, Indonesia \\ syaiful@ft.uika-bogor.ac.id
}

\begin{abstract}
Depok became a pilot as an orderly city with traffic arrangements and diverse patterns of population movement. The diversity of the city residents' trips has resulted in an increasingly diverse population passing through the region. Population mobility also requires adequate transportation facilities and infrastructure. This study aims to obtain traffic data and the level of noise pollution caused by the speed of motor vehicles (SPM, MP, MAU) in front of the Bunda Hospital Margonda Depok. The calculation and analysis obtained are on the equation with the first largest $R$ value on the second day of the third point study (Sound Level Meter 3 ), with a contribution of $50.50 \%$. As equation, $y=73.824+0.030 \times 1-0.020 \times 2-0.324 \times 3$, the addition of motorcycle density is 0.030 and the reduction in private car density and public transport car density is 0.344 , the noise pollution level will be reduced by $0.314 \mathrm{~dB}_{\mathrm{A}}$ in SLM3. The second largest $R$ value with motorcycle density, private car density and public transport car density has a moderate effect on noise pollution in the second day of the research point (Sound Level Meter2) with a contribution of $48.50 \%$.
\end{abstract}

Keywords: density; motor vehicle; sound level meter; noise pollution.

\section{INTRODUCTION}

Depok City is a buffer city of the capital of DKI Jakarta. Depok is directly adjacent to DKI Jakarta. Depok is also a pilot as an orderly city of traffic with various traffic flow settings and population movement patterns. The diversity of the city residents' trips has resulted in an increasingly diverse population passing through the region. Population mobility also requires adequate transportation facilities and infrastructure. Adequate facilities and infrastructure that meets the criteria such as safe, comfortable and affordable for the community (Ofyar Z Tamim, 2000; Suwardjoko, 2002). If examined further that the number of traffic flow in the city of Depok and the types of vehicles that use the Depok road section are also increasing. This increase problems in the field of transportation. The problem varies according to the speed of the vehicle such as air pollution due to exhaust gases, noise pollution due to motor vehicle engines, or congestion caused by the traffic flow (Syaiful, 2017; Syaiful Syaiful, Mikhael Yuliantino, 2017).

Noise pollution is the sound emitted by motor vehicles simultaneously on the highway, generally the noise pollution is related to the discomfort of the listeners around him. The noise generated by traffic vehicles becomes the dominant source of noise pollution that occurs in urban environments. The sources of noise caused by motorized vehicles are those related to transportation such as private cars, passenger cars, motor vehicles, buses, trucks and other heavy vehicles. Each vehicle produces a different sound, but the amount of sound produced varies greatly depending on the type of vehicle and the installed engine capacity that is owned. The greater the type of vehicle and engine capacity, the greater the sound produced, including 
the year of manufacture, the longer the year of manufacture the greater the sound generated (Syaiful Syaiful, Sri Wiwoho Mudjanarko, 2019).

Hospital area is expected to be free from an atmosphere that is not calm, quiet, noise pollution and noise. The area of the Bunda Hospital Margonda Depok is on the main Margonda Raya Rd which is passed by various types of vehicles. Vehicles that pass this road vary both light vehicles and heavy vehicles. The type of vehicle is the biggest contributor to noise pollution. This study aims to obtain traffic data and the level of noise pollution caused by the speed of motor vehicles (SPM, MP, MAU) in front of the Bunda Hospital Margonda Depok. Vehicles that pass certain roads will be subjected to construction on the road and will cause damage in accordance with the load it receives (Triyanto, Syaiful, Rulhendri, 2019; Maudiawan Mubarak, Rulhendri Rulhendri, Syaiful Syaiful, 2020). Every road construction especially concrete influences motor vehicle traffic (Syaiful Syaiful, Doni Haryadi, 2019; Syaiful Syaiful, Yogi Pratama, 2019; Syaiful Syaiful, 2020; Syaiful Syaiful, Lian Lasmana, 2020).

\section{Analysis of the condition of road network infrastructure}

The purpose of this stage is to find out in detail the conditions and characteristics of the road network infrastructure of each alternative service area produced in the previous stage. The characteristics and conditions of the road network baseline need to be known in detail, bearing in mind that the vehicle route to be planned will follow the existing road network infrastructure (Bukhari, 2007; Departemen Pekerjaan Umum, 1997; Hidayati, Nurul, 2004;)

\section{Vehicle density}

Each passing activity from one place to another will be measured in unity of time, the faster the way the shorter the time traveled. Likewise, with motor vehicles, the distance traveled in a time union by the vehicle is called vehicle density.

Vehicle density can be calculated by the equation (1)

$$
\mathrm{V}=\frac{\mathrm{S}}{\mathrm{T}}
$$

With:

$\mathrm{V}=$ Vehicle density $(\mathrm{km} / \mathrm{hour})$

$\mathrm{S} \quad=$ Distance traveled $(\mathrm{km})$

$\mathrm{T} \quad=$ Traveling time (hour)

Average density is calculated by the equation (2):

$$
V=\frac{(V M C \times n M C)+(V L V \times n L V)+(V H v \times n H V)}{n M C+L V+n H V}
$$

With:

$$
\begin{array}{ll}
\mathrm{Vr} & =\text { Average density } \\
\mathrm{VMC} & =\text { Motorcycle density } \\
\mathrm{nMC} & =\text { The number of motorcycles that crossed were sampled as observaions } \\
\mathrm{VLV} & =\text { Lightweight car density } \\
\mathrm{nLV} & =\text { The number of light cars that cross the sample observation } \\
\mathrm{VHV} & =\text { Heavy car density } \\
\mathrm{nH} & =\text { The number of heavy cars that crossed the observation sample }
\end{array}
$$




\section{Traffic density}

Traffic density is the number of vehicles occupying the length of a particular road or lane. Traffic density is calculated by the equation (3) dan (4):

$$
k=\frac{N}{L}
$$

With:

$$
\begin{array}{ll}
\mathrm{k} & =\text { Density } \\
\mathrm{N} & =\text { Number of vehicles } \\
\mathrm{L} & =\text { Path length } \\
\mathrm{k}= & \frac{\text { Volume }}{\text { average space speed }}
\end{array}
$$

Vehicle volume $=$ number of vehicles/hours

Average density $=$ distance/hour $(\mathrm{km} / \mathrm{hour})$

\section{Passenger car equivalent (EMP)}

The passenger car equivalent (EMP) for each type of vehicle depends on the type of road and the total traffic flow is expressed in 1 hour. All passenger car unit (PCU) values for different vehicles based on the EMP coefficient, to determine the equivalent of a passenger car are shown in Table 1, and the determination of the frequency of events is shown in Table 2.

Table 1. Determining the equivalence of passenger cars (EMP)

\begin{tabular}{lccc}
\hline $\begin{array}{c}\text { Road type }=\text { one-way street } \\
\text { and divided road }\end{array}$ & $\begin{array}{c}\text { Traffic flow per lane } \\
\text { (vehicle / hour) }\end{array}$ & HV & EMP \\
\hline Two lanes in one direction (2/1) & 0 & 1,3 & 0,40 \\
Four lanes divided (4/2D) & $>1050$ & 1,2 & 0,25 \\
Three lanes in one direction (3/1) & 0 & 1,3 & 0,40 \\
Six lanes divided (6/2 D) & $>1100$ & 1,2 & 0,25 \\
\hline
\end{tabular}

(Source: Departemen Pekerjaan Umum,1997)

Table 2. Determination of the frequency of events

\begin{tabular}{lcc}
\hline Type of Side Obstacle Event & Symbol & Weight Factor \\
\hline Pedestrian & PED & 0,5 \\
Parking, vehicle stops & PCV & 1,0 \\
Vehicle in + out & EEV & 0,7 \\
The vehicle is slow & SMV & 0,4 \\
\hline
\end{tabular}

(Source: Departemen Pekerjaan Umum,1997) 


\section{Road capacity/actual capacity}

Real capacity is defined as the maximum current through a point on the road which can be maintained by the unity of the clock under certain conditions. Capacity values are observed through field data collection as long as possible, because locations that have flows close to the capacity of the road segment are small (as seen from capacity along the road), and capacity is also estimated from an analysis of light traffic conditions.

Total capacity is the product of the basic capacity (Co) for certain conditions (ideal) and correlation factors $(F)$ by calculating the effect on capacity, where capacity is expressed in passenger car units ( $\mathrm{pcu}$ ). The basic equation for determining the capacity is:

C $=$ Co $\times$ FCw $\times$ FCsp $\times$ FCsf $x F C c s$

with:
C = Actual capacity [SMP/hour]
Co = Basic capacity (ideal) for certain ideal conditions [SMP/hour]
$\mathrm{FCw} \quad=$ Adjustment factor for capacity
FCsp = Adjustment factor for current separator capacity
FCsf = Adjustment factor for side barriers 2 shoulder capacities
FCcs = Adjustment factor for city size capacity

The adjustment factor is obtained from the table. If the actual conditions are the same as a certain (ideal) base case, then all the adjustment factors become 1.0 and the capacity becomes the same as the basic capacity (Co). The FCw capacity adjustment is shown in Table 4 and the FCsp capacity adjustment factor is shown in the Table 3, Table 4 and Table 5.

Table 3. Base capacity Co for urban roads

\begin{tabular}{lcc}
\hline \multicolumn{1}{c}{ Road tyipe } & $\begin{array}{c}\text { Actual capacity } \\
\text { (SMP/hour) }\end{array}$ & Note \\
\hline Four divided lanes or one-way streets & 1659 & Per lane \\
Four lanes not divided & 1500 & Per lane \\
Two undivided lanes & 2900 & Two ways total \\
\hline
\end{tabular}

(Source: Departemen Pekerjaan Umum,1997)

Table 4. Adjustment of FCw capacity for the influence of the width of the traffic lane for urban roads

\begin{tabular}{lccc}
\hline \multicolumn{1}{c}{ Road type } & $\begin{array}{c}\text { Effective traffic lane width } \\
\text { (Wc) }\end{array}$ & FCw \\
& & (M) & \\
\hline Four divided lanes or & Per lane & 3,00 & 0,92 \\
one-way streets & & 3,25 & 0,96 \\
& & 3,50 & 1,00 \\
& 3,75 & 1,04 \\
& & 4,00 & 1,08 \\
\hline Four lanes not divided & Per lane & 3,00 & 0,91 \\
& & 3,25 & 0,95 \\
& & 3,50 & 1,00 \\
\hline
\end{tabular}




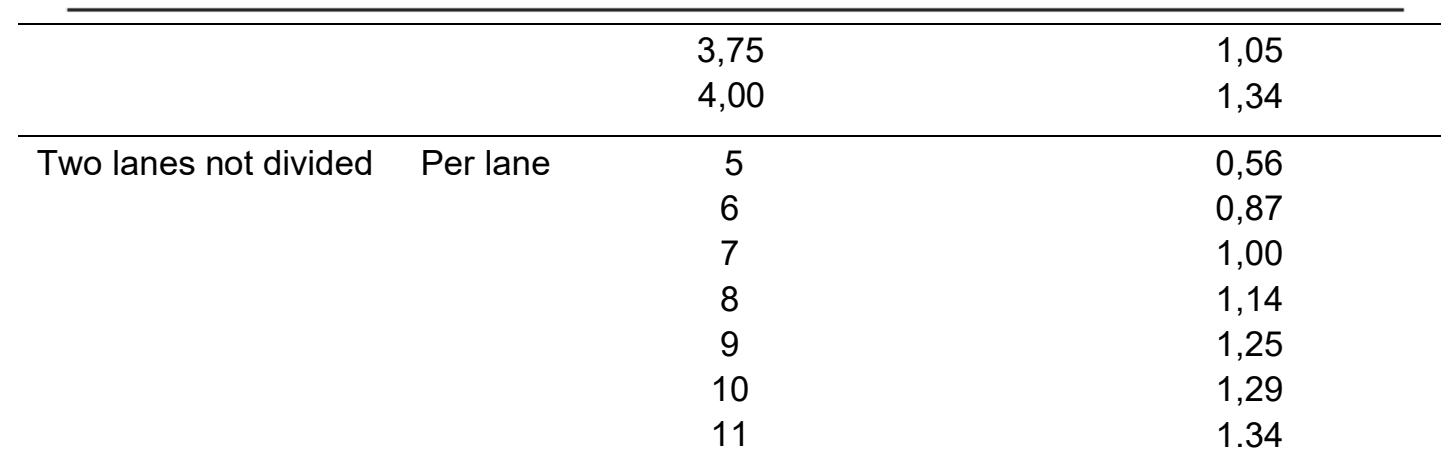

(Source: Departemen Pekerjaan Umum,1997)

Table 5. Capacity adjustment factors for directional separators (FCsp)

\begin{tabular}{cccccccc}
\hline $\begin{array}{c}\text { Directional separatorSP } \\
\mathbf{\%}-\%\end{array}$ & $\mathbf{5 0 - 5 0}$ & $\mathbf{6 0 - 4 0}$ & $\mathbf{7 0 - 3 0}$ & $\mathbf{8 0 - 2 0}$ & $\mathbf{9 0 - 1 0}$ & $\mathbf{1 0 0 - 0}$ \\
\hline \multirow{2}{*}{ FCsp } & Two lanes 2/2 & 1,00 & 0,94 & 0,88 & 0,82 & 0,76 & 0,70 \\
\cline { 2 - 8 } & Four lanes 4/2 & 1,00 & 0,97 & 0,94 & 0,91 & 0,88 & 0,85 \\
\hline
\end{tabular}

\section{Sound pollution}

Noise pollution is unwanted noise from businesses or activities at a certain level and time that can cause human health problems and environmental comfort (Menteri Negara Lingkungan Hidup, 1996). Based on the nature and spectrum of sound, noise pollution is divided into:

1. Noise that is continuous with a wide frequency spectrum, this noise is relatively fixed within the limit of approximately $5 \mathrm{~dB}_{\mathrm{A}}$ for a period of 0.5 seconds in a row.

2. Noise that is continuous with a narrow frequency spectrum, noise is also relatively fixed, but only has a certain frequency (frequencies $500 \mathrm{~Hz}, 1000 \mathrm{~Hz}$, and $4000 \mathrm{~Hz}$ ) such as secular saws, gas valves.

3. Noise intermittent, this noise does not occur continuously, but there is a relatively quiet period, such as traffic noise, noise at the airport.

4. Noisy impulsive. This type of noise has a change in sound pressure exceeding $40 \mathrm{~dB}_{\mathrm{A}}$ in a very fast time and is usually shocking to his hearing, for example shots, fireworks, guns.

5. Repeated impulsive noise. This noise is the same as impulsive noise, only here it happens repeatedly, for example a forging machine.

Type of environmental noises can be seen in Table 6, while table 7 is shown the effects of noise.

Table 6. Types of environmental noise

\begin{tabular}{ll}
\hline \multicolumn{1}{c}{ Definition of Description } & \multicolumn{1}{c}{ Definition of Description } \\
\hline $\begin{array}{l}\text { Total noise All noise in all places at any given } \\
\text { time. }\end{array}$ & $\begin{array}{l}\text { Total noise All noise in all places at any } \\
\text { given time. }\end{array}$ \\
\hline $\begin{array}{l}\text { Specific noise Noise between the amount of } \\
\text { noise that can be clearly distinguished for }\end{array}$ & $\begin{array}{l}\text { Specific noise Noise between the amount } \\
\text { of noise that can be clearly distinguished } \\
\text { acoustic reasons. Often the source of noise can } \\
\text { fe identified. }\end{array}$ \\
\hline
\end{tabular}


THE SPIRIT OF SOCIETY JOURNAL

International Joumal of Society Development and Engagement

ISSN : 2597-4777 (Online) - ISSN : 2597-4742 (Print)

This work is licensed under a Creative Commons Attrib ution-ShareAlike 4.0 International License.

Residual noise Noise that remains after eliminating all specific noise from the amount of noise at a certain place in a certain time.
Residual noise Noise that remains after eliminating all specific noise from the amount of noise at a certain place in a certain time.

Background noise All other noise when focusing Background noise All other noise when on a particular noise. focusing on a particular noise.

(Source: Menteri Negara Lingkungan Hidup, 1996)

Table 7. Effects of noise

\begin{tabular}{lll}
\hline \multicolumn{1}{c}{ Types } & & \multicolumn{1}{c}{ Descriptions } \\
\hline Physical consequences & Hearing loss & $\begin{array}{l}\text { Temporary change in threshold due to } \\
\text { noise. }\end{array}$ \\
\hline Physical consequences & $\begin{array}{l}\text { As a result of } \\
\text { physiology }\end{array}$ & $\begin{array}{l}\text { Permanent change in threshold due to } \\
\text { noise }\end{array}$ \\
\hline Psychological consequences & $\begin{array}{l}\text { Emotional } \\
\text { disturbance }\end{array}$ & $\begin{array}{l}\text { Aggreased discomfort or stress, increased } \\
\text { blood pressure, headaches, ringing. }\end{array}$ \\
\hline Psychological consequences & $\begin{array}{l}\text { Lifestyle } \\
\text { disorders }\end{array}$ & $\begin{array}{l}\text { Sleep deprivation or rest, lost } \\
\text { concentration when working, reading, etc. }\end{array}$
\end{tabular}

(Source: Menteri Negara Lingkungan Hidup.1996)

These limits on noise levels for some regions or environments can be seen in Table 8:

Table 8. Limitation of noise levels

\begin{tabular}{lc}
\hline \multicolumn{1}{c}{ Allotment of health area/environment } & Noise level $\left(\mathbf{d B}_{\mathbf{A}}\right)$ \\
\hline 1. Allocation of the area & 55 \\
a. Housing and settlement & 70 \\
b. Trade and services & 65 \\
c. Office and trade & 50 \\
d. Room is open green & 70 \\
e. Industry & 60 \\
f. Government and public facilities & 70 \\
g. Recreation & 55 \\
\hline 2. Activity environment & 55 \\
a. Hospital or the like & 55 \\
b. School or the like & \\
c. Places of worship or the like & \\
\hline
\end{tabular}

(Source: Menteri Negara Lingkungan Hidup.1996)

\section{Data analysis}

Analysis of the data observing the level of noise pollution on a straight road with the type of hospital research object. In this case it is assumed that the increase in noise pollution level $(Y)$ is 
an independent variable. These independent variables will be influenced by several independent variables, namely:

$\mathrm{X} 1$ is the first free variable/motorcycle speed (SPM)

$\mathrm{X} 2$ is the second free variable/personal car speed (MP)

$\mathrm{X} 3$ is the third independent variable/passenger public transport speed (MAU)

Based on the data above we get the linear regression model approach, namely:

$Y=a 0+a 1 . X 1+a 2 . X 2+a 3 . X 3$

The coefficients of each ao, a1, a2 and a3 are coefficients determined based on research data.

\section{RESEARCH METHODS}

\section{Retrieval of field data}

Field data collection was carried out for 4 days, namely:

1. Wednesday, February 26,2014 ,

2. Thursday, February 27,2014 ,

3. Friday February 28,2014 , and

4. Saturday, March 12014.

\section{Location and place of research}

The location and place of research are in front of Bunda Hospital Margonda Depok, precisely on the Margonda Raya Rd Depok.
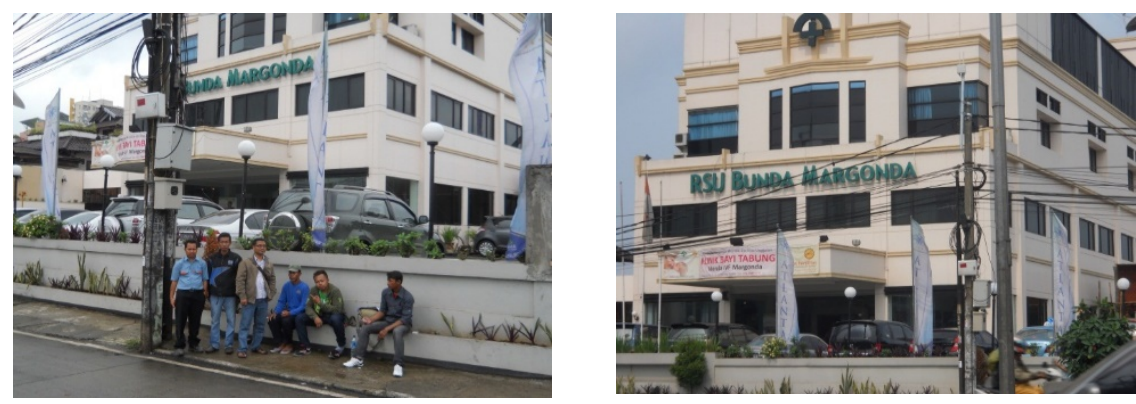

Figure 1. Front of Bunda Hospital, Margonda Depok

\section{Materials}

The material in this study uses forms to record data, be it data on the number of motor vehicle, private cars and public transport cars and noise pollution data taken simultaneously using Sound Level Meter (SLM).

\section{Equipment}

The tools used in this study are as follows:

1. Sound Level Meter (SLM), as the main tool to calculate the noise that occurs at a certain place and time. SLM used there are fruits, which include:

a) SLM 1, SLM Manual Krisbow brand, type KW06-291, 
b) SLM 2, SLM Krisbow brand Manual, type KW06-291, and

c) SLM 3, SLM Outo brand Extech, type HD600.

2. Roller Meter, as a tool to measure the distance between the SLM point with the road and hospital wall building.

3. Digital cameras, to document all processes in the ongoing research.

4. Tally or manual counters, as a tool to count the number of vehicles that pass on the highway.

5. Laptops, as a tool in collecting data and processing data obtained from the field during the research.

6. Stationary and registrar in the field, his job is to help record matters related to data collection in the field.

\section{Research flowchart}

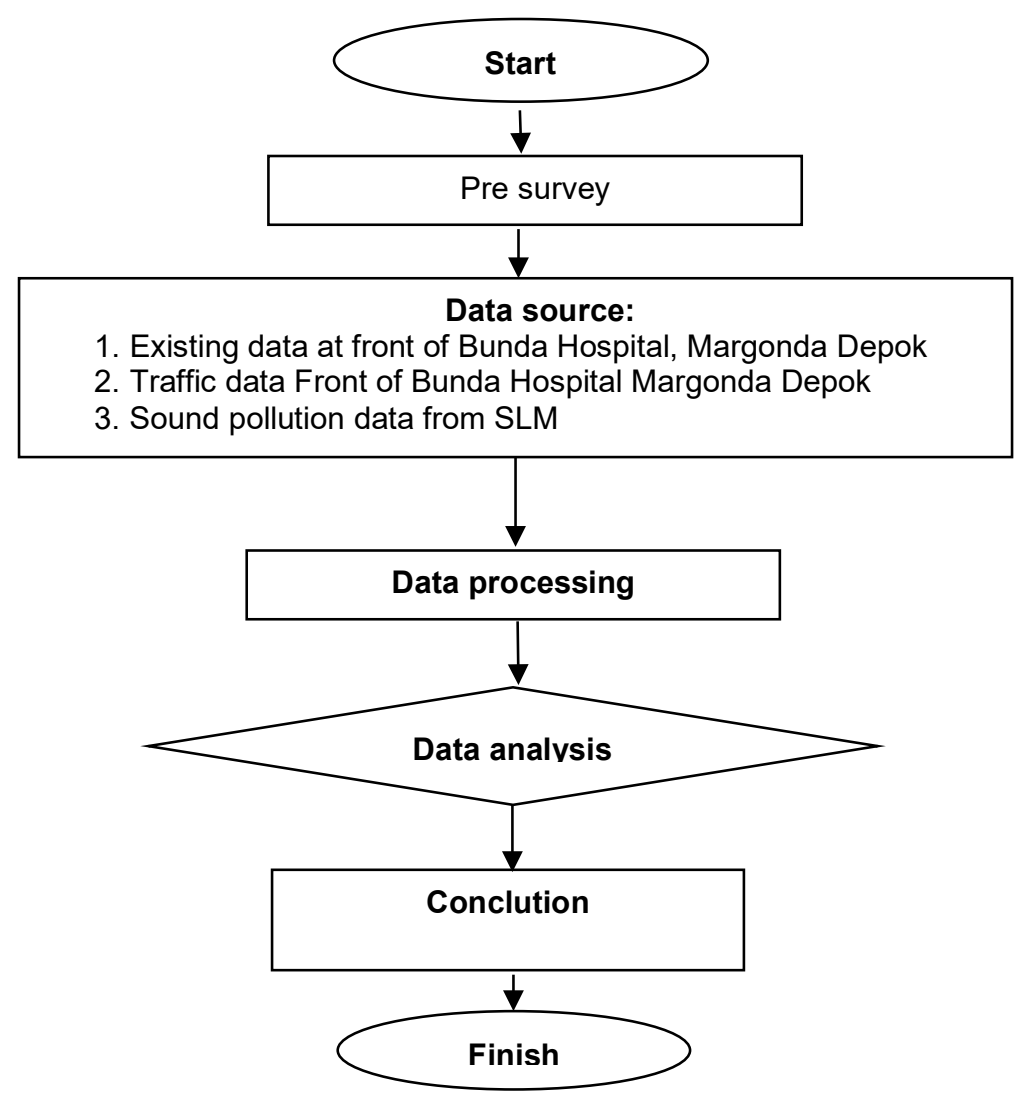

Figure 2. Research flowchart

\section{RESULTS AND DISCUSSION}

\section{Traffic data results}

Traffic data that calculated is the data per 15 minutes for 12 hours a day. Data is collected starting at 6:00 until 18:00. This data was taken for 4 days, namely on Wednesday/February 26, 2014- Thursday/February 27, 2014-Friday/February 2014 and Saturday/March 01, 2014. 
Data on traffic results is obtained from the calculation of Passenger Car Equivalence (EMP). The use of this calculation is intended to make it easy to analyze the traffic of passenger car units (SMP) for each motorized vehicle according to the Indonesian Road Capacity Manual (Departemen Pekerjaan Umum, 1997), for urban roads are as follows:

1) Heavy Vehicle (HV) $\quad=1.30$

2) Light Vehicles (LV) $\quad=1.00$

3) Motorcycle (MC) $\quad=0.40$

4) Non motorcycles $\quad=1.00$

In its implementation the grouping is divided into two groups, namely motor vehicle and light vehicles, where motorcycles (MC) with a value of 0.40 and light vehicles are included (private cars, public transportation and freight transportation) with EMP 1,00.

\section{Data on Wednesday, February 26, 2014}

From the research carried out below, the number of motor vehicle, private car and public transport car data for two directions, namely to the Pasar Minggu and Depok, the highest number of motorbikes at 17.15-17.30 amounted to 2,975, private cars at 07.45-08.00 at 538 and public transport cars at 12:30 a.m. to 12:45 amounting to 266 from the Pasar Minggu and Depok.

\section{Data on Thursday, February 27, 2014}

From the research carried out below, the number of motor vehicle, private car and public transport cars presented in two directions, namely to the Pasar Minggu and Depok, the highest number of motorbikes at 06:45 to 08:00 amounted to 2,598, private cars at 17.30-17.45 amounted to 821 and public transport cars at $15.15-15.30$ for 288 from the Pasar Minggu and Depok.

\section{Data on Friday, February 28, 2014}

From the research carried out below, the number of motor vehicle, private car and public transport car data for two directions, namely to the Pasar Minggu and Depok, the highest number of motorbikes at $06.45-07.00$ is 3,716 , private cars at $15.30-15.45$ are 964 and public transportation cars at 16.30-16.45 totaling 221 from two directions on the Pasar Minggu and Depok.

\section{Data on Saturday March 12014}

From the research carried out below, the number of motor vehicle, private car and public transport cars presented in two directions, namely to the Pasar Minggu and Depok, the highest number of motorbikes at $17: 45$ to $18: 00$ is 3,587 , private cars at $07: 45$ to $08: 00$ by 1,234 and public transport cars at 14.15-14.30 totaling 224 from the Pasar Minggu and Depok.

\section{Calculation of Data Processing Results for Density}

Calculation of the results of processing density is based on the calculation of density guidelines from Department of Highways, Republic of Indonesia Public Works Department. Data collection starts with calculating the density of the formula as below:

$$
\begin{aligned}
\text { Density of private car (D) } & =\frac{\text { Volume }(\mathrm{Q})}{\text { Speed (U) }} \\
\text { D } & =\text { vehicle } / \mathrm{km}
\end{aligned}
$$

A sample of the density calculation for a motorcycle on the first day is displayed. 
Wednesday February 26, 2014 for the first minute calculation of 6:00 to 06:15 is:

Known :

Volume $(Q) \quad=9.424,00$ vehicles/hours

Speed $(U) \quad=2.356,00 \mathrm{~km} / \mathrm{hours}$

So:

Density (D)

$=\underline{\text { Volume }(\mathrm{Q})}$

Speed (U)

$=\underline{9.424,00 \text { vehicles } / \text { hours }}$

$2.356,00 \mathrm{~km} / \mathrm{hours}$

Obtained results

Density $(D) \quad=261,78$ vehicles $/ \mathrm{km}$

\section{Results of taking SLM on Wednesday/February 26, 2014}

From the results of SLM data collection at a distance of $0.00 \mathrm{~m} 3.00$ and $15.00 \mathrm{~m}$ from the edge of the highway is shown in table 9 below.

Table 9. Sound level meter distance $0,00,3,00$ and $15,00 \mathrm{~m}$ from the edge of the highway

Wednesday/February 26, 2014

SLM anda density of motor vehicles

\begin{tabular}{ccccccc}
\hline No & SPM/X1 & MP/X2 & MAU/X3 & SLM1 & SLM2 & SLM3 \\
\hline 1 & 261.78 & 44.86 & 17.00 & 82.00 & 74.30 & 71.00 \\
\hline
\end{tabular}

Results of taking SLM on Thursday/February 27, 2014.

From the results of SLM data collection at a distance of $0.00 \mathrm{~m} 3.00$ and $15.00 \mathrm{~m}$ from the edge of the highway shown in table 10 below.

Table 10 Sound level meter distance $0,00,3,00$ and 15,00 m from the edge of the highway

\section{Thursday/February 27, 2014}

SLM and density of motor vehicles

\begin{tabular}{ccccccc}
\hline No & SPM/X1 & MP/X2 & MAU/X3 & SLM1 & SLM2 & SLM3 \\
\hline 1 & 221.68 & 51.88 & 15.26 & 83.10 & 76.40 & 73.20
\end{tabular}

Results of taking SLM on Friday/February 28, 2014.

From the results of SLM data collection at a distance of $0.00 \mathrm{~m} 3.00$ and $15.00 \mathrm{~m}$ from the edge of the highway is shown in table 11 below.

Table 11. Sound level meter distance $0,00,3,00$ and $15,00 \mathrm{~m}$ from the edge of the highway

\section{Friday/February 28, 2014}

SLM and density of motor vehicles

\begin{tabular}{ccccccc}
\hline No & SPM/X1 & MP/X2 & MAU/X3 & SLM1 & SLM2 & SLM3 \\
\hline 1 & 235.39 & 29.35 & 12.85 & 90.20 & 85.50 & 80.50 \\
\hline
\end{tabular}


Results of taking SLM on Saturday March 01, 2014.

From the results of SLM data collection at a distance of $0.00 \mathrm{~m} 3.00$ and $15.00 \mathrm{~m}$ from the edge of the highway is shown in table 12 below.

Table 12. Sound level meter distance $0,00,3,00$ and $15,00 \mathrm{~m}$ from the edge of the highway Saturday/March 01, 2014

\begin{tabular}{ccccccc}
\hline \multicolumn{7}{c}{ SLM and density of motor vehicles } \\
\hline No & SPM/X1 & MP/X2 & MAU/X3 & SLM1 & SLM2 & SLM3 \\
\hline 1 & 243.29 & 21.91 & 11.70 & 83.10 & 80.20 & 78.60
\end{tabular}

\section{Discussion of Pollution Results due to Motorized Vehicles}

From the results of data processing in the field and processing using the SPSS version 17.00 program, the selection of available data is carried out, so that the calculation on the attachment page is obtained. The following shows that the data recommended below are data on motorcycle density, private car density and passenger public transport density.

\section{Correlation Testing Results}

Testing the correlation results is looking for a relationship between two or more independent variables together and related to the dependent variable, so that it can be seen how much the contribution of the independent variable which is the object of research on the dependent variable.

Table 13. Interpretation Relations of $R$ Square Values

\begin{tabular}{ccc}
\hline No & Score $\mathbf{R}$ & Interpretation of R values \\
\hline 1 & 0 & Uncorrelated \\
2 & $0,01-0,20$ & Very low \\
3 & $0,21-0,40$ & Low \\
4 & $0,41-0,60$ & Rather low \\
5 & $0,61-0,80$ & High enough \\
6 & $0,81-0,99$ & High \\
7 & 1 & Very high \\
\hline
\end{tabular}

\section{Hypothesis}

$\mathrm{Ha} \quad=$ There is a significant effect between motorcycle density, private car density and public passenger car density with noise pollution.

Ho = There is no significant effect between motorcycle density, private car density and public passenger car density with noise pollution.

$\alpha \quad=5.00 \%$

Discussion of Statistical Analysis on Wednesday/February 26, 2014

Discussion of SLM1 analysis with a distance of $0.00 \mathrm{~m}$ from the edge of the highway.

Data processing and discussion using the SPSS program version 17.00 obtained the level of noise pollution ( $y$ ) and motorcycle density (SPM/x1), private car density (MP/x2) and the density of passenger public transport cars (MAU/x3). Data calculation and processing is based 
on a $95 \%$ confidence level. The results and discussion of the equations representing field conditions are shown as follows, $y=79.009+0.009 \times 1+0.006 \times 2+0.137 \times 3$.

\section{Test Criteria}

Discussion of testing the summary model obtained by the value of $R=0.133$ which means that $x 1, x 2$ and $x 3$ have an effect of $13.30 \%$ on $y$.

ANOVA test results obtained $\mathrm{F}$-count value $=0.263$ with a probability value $(\mathrm{sig})=0.851$. From the input data we get the value of F-Table $=2.816$ so $\mathrm{F}$-Calculate $<\mathrm{F}$-Table, then $\mathrm{Ha}$ is rejected and $\mathrm{Ho}$ is accepted.

Discussion of coefficients test results, motorcycle density, private car density and public transport car density have constant values $(a)=79.873$, (b) $=0.009$, (c) $=0.006$, (d) $=0.137$ and $\mathrm{t}$-count $=11.753$ and the value $(\mathrm{sig})=0.000$, from the data obtained the value of $\mathrm{t}$-Table $=2015$, then $\mathrm{t}$-Calculate $>\mathrm{t}$-Table, then $\mathrm{Ha}$ is accepted and $\mathrm{Ho}$ is rejected.

Table 14. ANOVA Test Results on SLM1 for motorcycle density (SPM), private car density (MP) and public passenger car density (MAU)

\section{ANOVA $^{\text {b }}$}

\begin{tabular}{|ll|r|r|r|r|r|}
\hline \multicolumn{1}{|l|}{} & Sum of Squares & df & Mean Square & F & \multicolumn{1}{c|}{ Sig. } \\
\hline 1 & Regression & 14.313 & 3 & 4.771 & .263 & $.851^{\mathrm{a}}$ \\
& Residual & 796.889 & 44 & 18.111 & & \\
& Total & 811.202 & 47 & & & \\
\hline
\end{tabular}

a. Predictors: (Constant), Density.MAU, Density.SPM, Density.MP

b. Dependent Variable: SLM1

\section{Hypothesis decision}

The results of the test statistics above can be drawn from the decision of the hypothesis that the effect of motor vehicle density on noise pollution is very small and there is no significant influence or relationship between motor vehicle density on noise pollution that occurs on SLM1 on the first day.

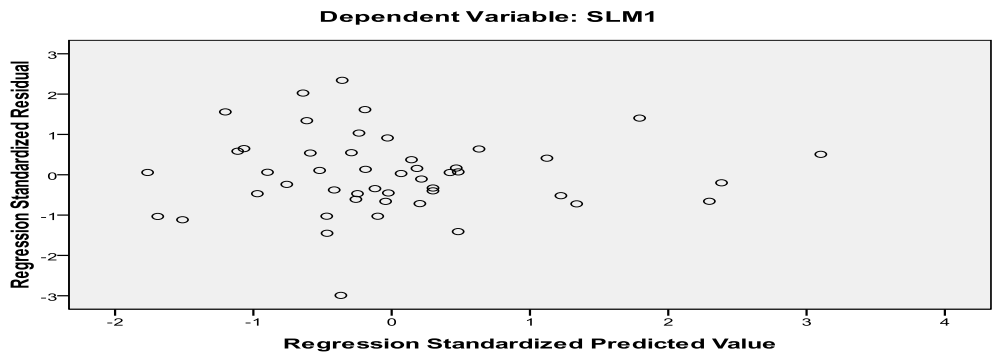

Figure 3. Spread of the SLM1 Scatterplot test for motorcycle density (SPM), private car density (MP) and public passenger car density (MAU).

\section{Discussion of SLM2} $-0.529 \times 3$.

Analysis distance of $3.00 \mathrm{~m}$ from the edge of the highway $\mathrm{y}=86.635+0.012 \times 1-0.020 \times 2$ 


\section{Test Criteria}

Discussion of testing the summary model obtained by the value of $R=0.423$ which means that $x 1, x 2$ and $x 3$ have an effect of $42.30 \%$ on $y$.

Table 15. ANOVA Test Results on SLM2 for motorcycle density (SPM), private car density (MP) and public passenger car density (MAU)

ANOVA $^{\mathrm{b}}$

\begin{tabular}{|ll|r|r|r|r|r|}
\hline Model & & Sum of Squares & df & Mean Square & F & \multicolumn{1}{l|}{ Sig. } \\
\hline 1 & Regression & 227.182 & 3 & 75.727 & 2.8162 & $.033^{2}$ \\
& Residual & 1043.961 & 44 & 23.726 & & \\
& Total & 1271.143 & 47 & & & \\
\hline
\end{tabular}

a. Predictors: (Constant), Density.MAU, Density.SPM, Density.MP

b. Dependent Variable: SLM2

\section{Hypothesis decision}

The results of the test statistics above can be drawn from the decision of the hypothesis that the effect of motor vehicle density on noise pollution is very small and there is no significant influence or relationship between motor vehicle density on noise pollution that occurs on SLM2 on the first day.

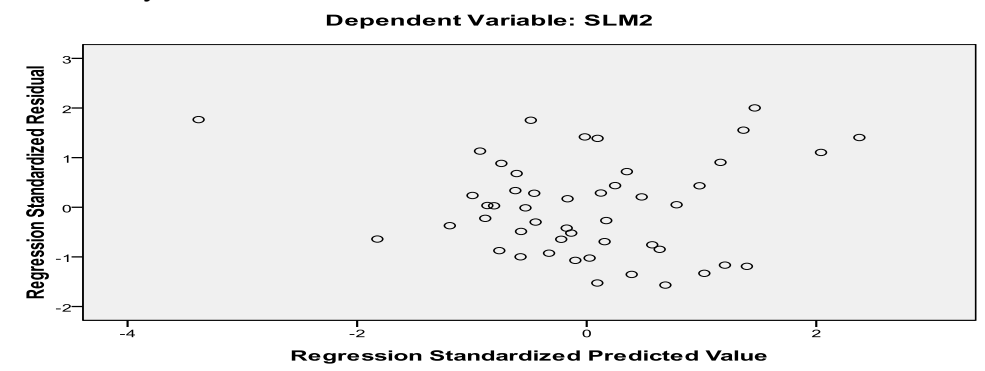

Figure 4. Spread of the SLM2 Scatterplot test for motorcycle density (SPM), private car density (MP) and public passenger car transport density (MAU).

The discussion of SLM3

Analysis is the distance of $15.00 \mathrm{~m}$ from the edge of the highway $\mathrm{y}=73.651-0.002 \times 1+$ $0.016 \times 2-0.1184 \times 3$.

\section{Test Criteria}

Discussion of testing the summary model obtained by the value of $R=0.198$ which means that $x 1, x 2$ and $x 3$ have an effect of $19.80 \%$ on $y$. 
THE SPIRIT OF SOCIETY JOURNAL

International Joumal of Society Development and Engagement

ISSN : 2597-4777 (Online) - ISSN : 2597-4742 (Print)

This work is licensed under a Creative Commons Attrib ution-ShareAlike 4.0 International License.

Table 16. ANOVA Test results on SLM3 for motorcycle density (SPM), private car density (MP) and public passenger car density (MAU)

ANOVA $^{\mathrm{b}}$

\begin{tabular}{|l|r|r|r|r|r|}
\hline Model & Sum of Squares & df & Mean Square & F & \multicolumn{1}{c|}{ Sig. } \\
\hline $1 \quad$ Regression & 10.184 & 3 & 3.395 & .597 & .620 \\
Residual & 250.152 & 44 & 5.685 & & \\
Total & 260.336 & 47 & & & \\
\hline
\end{tabular}

a. Predictors: (Constant), Density.MAU, Density.SPM, Density.MP

b. Dependent Variable: SLM3

\section{Hypothesis decision}

The results of the test statistics above can be drawn from the decision of the hypothesis that the effect of motor vehicle density on noise pollution is very small and there is no significant influence or relationship between motor vehicle density on noise pollution that occurs on SLM3 on the first day.

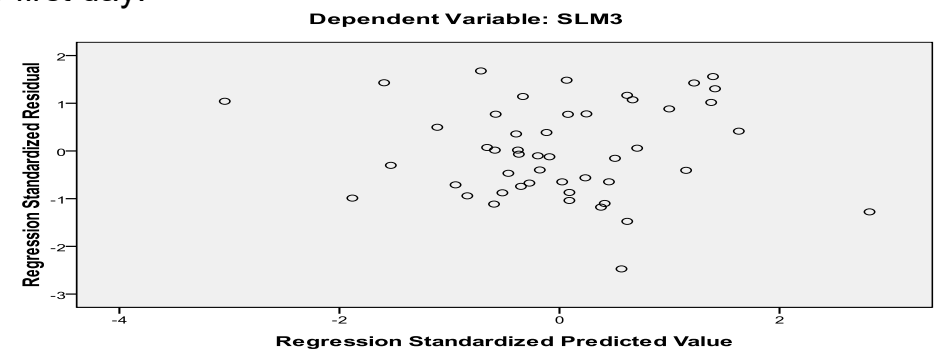

Figure 5. Spread of the SLM3 Scatterplot test for motorcycle density (SPM), private car density (MP) and passenger public transport car density (MAU).

\section{Discussion of Statistical Analysis on Thursday/February 27, 2014}

Discussion of SLM1 analysis is the distance of $0.00 \mathrm{~m}$ from the edge of the highway $\mathrm{y}=$ $83.078+0.021 \times 1-0.037 \times 2+0.028 \times 3$

\section{Test Criteria}

Discussion of testing the summary model obtained by the value of $R=0.351$ which means that $x 1, x 2$ and $x 3$ have an effect of $35.10 \%$ of $y$.

Table 17. ANOVA Test Results on SLM1 for motorcycle density (SPM), private car density (MP) and public passenger car density (MAU)

\section{ANOVA $^{b}$}

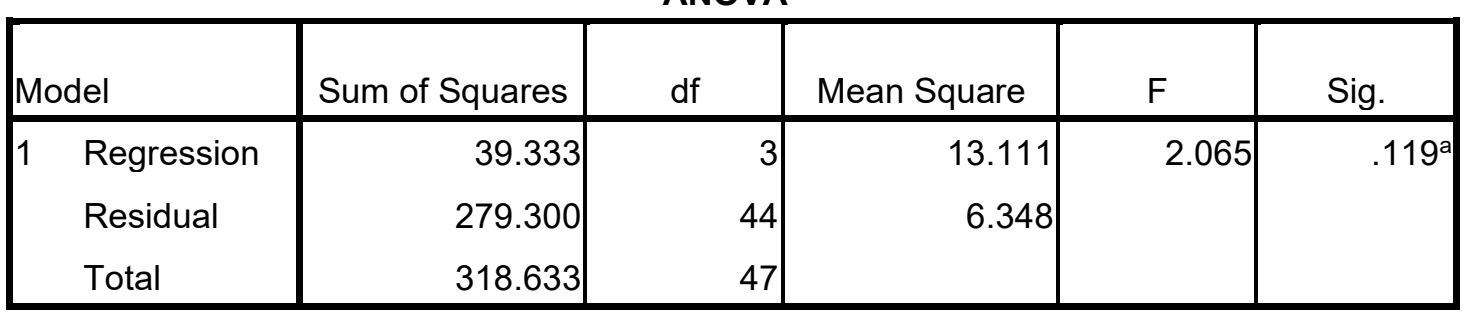

a. Predictors: (Constant), Density.MAU, Density.SPM, Density.MP

b. Dependent Variable: SLM1 


\section{Hypothesis decision}

The results of the test statistics above can be drawn from the decision of the hypothesis that the effect of motor vehicle density on noise pollution is very small and there is no significant influence or relationship between motor vehicle density on noise pollution that occurs on SLM1 on the second day

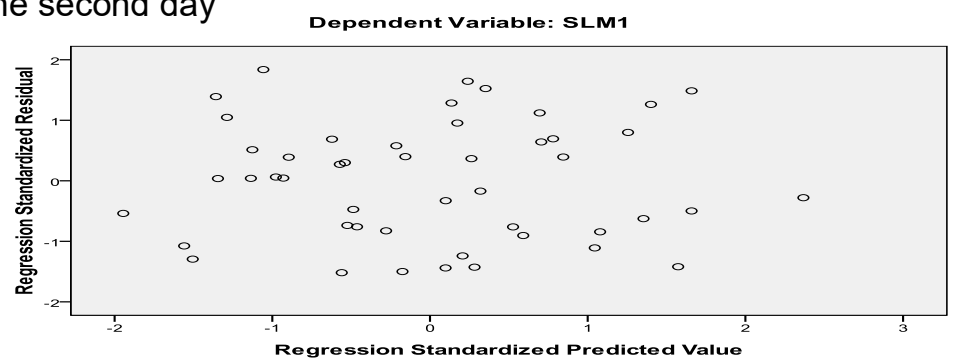

Figure 6. Spread of the SLM1 Scatterplot test for motorcycle density (SPM), private car density (MP) and passenger public transport car density (MAU).

\section{Discussion of SLM2}

$-0.191 \times 3$.

Analysis distance of $3.00 \mathrm{~m}$ from the edge of the highway $\mathrm{y}=74.885+0.024 \times 1-0.016 \times 2$

\section{Test Criteria}

Discussion of testing the summary model obtained by the value of $R=0.485$ which means that $x 1, x 2$ and $x 3$ have an effect of $48.50 \%$ on $y$.

Table 18. ANOVA Test Results on SLM2 for motorcycle density (SPM), private car density (MP) and public passenger car density (MAU)

\begin{tabular}{|c|c|c|c|c|c|c|}
\hline \multicolumn{7}{|c|}{ ANOVA $^{b}$} \\
\hline \multicolumn{2}{|c|}{ Model } & Sum of Squares & df & Mean Square & $\mathrm{F}$ & Sig. \\
\hline 1 & Regression & 65.065 & 3 & 21.688 & 4.506 & $.008^{a}$ \\
\hline & Residual & 211.785 & 44 & 4.813 & & \\
\hline & Total & 276.850 & 47 & & & \\
\hline
\end{tabular}

a. Predictors: (Constant), Density.MAU, Density.SPM, Density.MP

b. Dependent Variable: SLM2

\section{Hypothesis decision}

Discussion of the results of the test statistics above can be drawn from the decision of the hypothesis that the effect of motor vehicle density on noise pollution is very small and there is no significant influence or relationship between motor vehicle density on noise pollution that occurs on SLM2 on the second day. 
THE SPIRIT OF SOCIETY JOURNAL

International Joumal of Society Development and Engagement

ISSN : 2597-4777 (Online) - ISSN : 2597-4742 (Print)

This work is licensed under a Creative Commons Attrib ution-ShareAlike 4.0 International License.

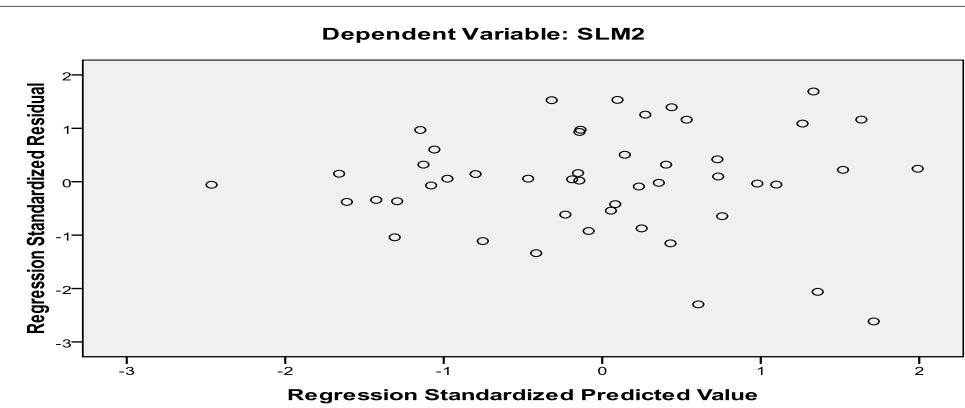

Figure 7. Spread of the SLM2 Scatterplot test for motorcycle density (SPM), private car density (MP) and public passenger car density (MAU).

\section{Discussion of SLM3}

$-0.324 \times 3$.

Analysis distance of $15.00 \mathrm{~m}$ from the edge of the highway $\mathrm{y}=73.824+0.030 \times 1-0.020 \times 2$

\section{Test Criteria}

Discussion of testing the summary model obtained by the value of $R=0.505$ which means that $x 1, x 2$ and $x 3$ have an effect of $50.50 \%$ on $y$.

Table 19. ANOVA Test Results on SLM3 for motorcycle density (SPM), private car density (MP) and public passenger car density (MAU)

\begin{tabular}{|c|c|c|c|c|c|c|}
\hline \multicolumn{7}{|c|}{ ANOVA $^{\mathrm{b}}$} \\
\hline \multicolumn{2}{|c|}{ Model } & Sum of Squares & $\mathrm{df}$ & Mean Square & $\mathrm{F}$ & Sig. \\
\hline 1 & Regression & 132.679 & 3 & 44.226 & 5.026 & $.004^{\mathrm{a}}$ \\
\hline & Residual & 387.200 & 44 & 8.800 & & \\
\hline & Total & 519.879 & 47 & & & \\
\hline
\end{tabular}

a. Predictors: (Constant), Density.MAU, Density.SPM, Density.MP

b. Dependent Variable: SLM3

\section{Hypothesis decision}

Discussion of the results of the test statistics above can be drawn from the results of the hypothesis decision that the effect of motor vehicle density on noise pollution is very small and there is no significant influence or relationship between motor vehicle density on noise pollution that occurs on SLM3 on the second day.

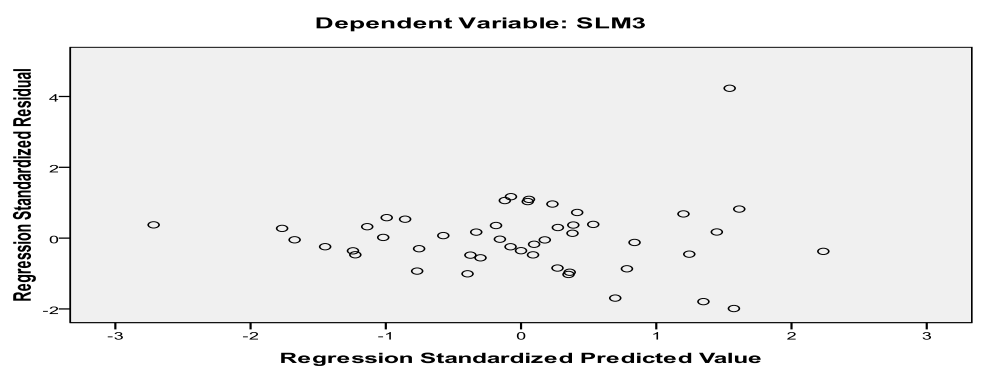

Figure 8. Distribution of the SLM3 Scatterplot test for motorcycle density (SPM), private car density (MP) and public passenger car density (MAU) 
Discussion of Statistical Analysis on Friday/February 28, 2014

Discussion of SLM1 analysis distance of $0,00 \mathrm{~m}$ from the edge of the highway $\mathrm{y}=91,938$ $-0,008 \times 1-0,036 \times 2-0,086 \times 3$.

\section{Test Criteria}

Discussion of testing the summary model obtained by the value of $R=0.337$ which means that $x 3$ has an effect of $33.70 \%$ on $y$.

Table 19. ANOVA Test Results on SLM1 for motorcycle density (SPM), private car density (MP) and public passenger car density (MAU)

\section{ANOVA $^{\mathrm{b}}$}

\begin{tabular}{|l|r|r|r|r|c|}
\hline Model & Sum of Squares & df & Mean Square & F & \multicolumn{1}{c|}{ Sig. } \\
\hline $1 \quad$ Regression & 59.049 & 3 & 19.683 & 1.885 & $.146^{a}$ \\
Residual & 459.511 & 44 & 10.443 & & \\
\multicolumn{1}{l|}{ Total } & 518.560 & 47 & & & \\
\hline
\end{tabular}

a. Predictors: (Constant), Density.MAU, Density.SPM, Density.MP

b. Dependent Variable: SLM1

\section{Hypothesis decision}

The results of the test statistics above can be drawn from the decision of the hypothesis that the effect of motor vehicle density on noise pollution is very small and there is no significant influence or relationship between motor vehicle density on noise pollution that occurs on SLM1 on the third day.

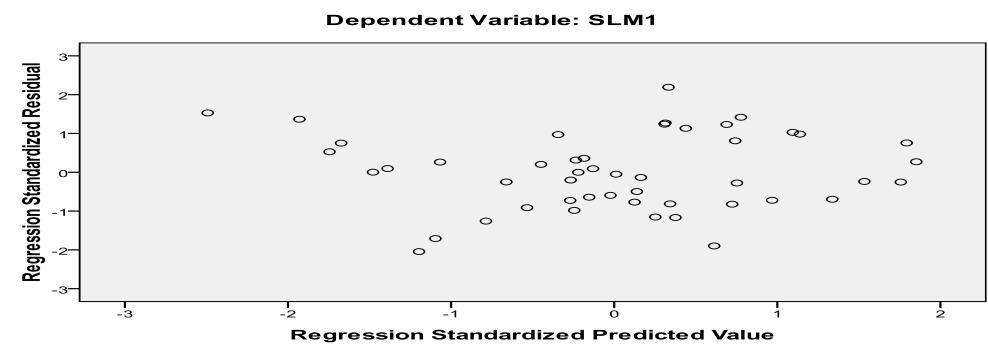

Figure 9. Distribution of the SLM1 Scatterplot test for motorcycle density (SPM), private car density (MP) and public passenger car density (MAU).

\section{Discussion of SLM2}

\section{Test Criteria}

Analysis distance of $3.00 \mathrm{~m}$ from the edge of the highway $\mathrm{y}=84.469-0.002 \times 1-0.036 \times 2$.

Discussion of testing the summary model obtained by the value of $R=0.269$ which means that $x 1, x 2$ and $x 3$ have an effect of $26.90 \%$ on $y$. 
THE SPIRIT OF SOCIETY JOURNAL

International Joumal of Society Development and Engagement

ISSN : 2597-4777 (Online) - ISSN : 2597-4742 (Print)

This work is licensed under a Creative Commons Attrib ution-ShareAlike 4.0 International License.

Table 20. ANOVA Test Results on SLM2 for motorcycle density (SPM), private car density (MP) and public passenger car density (MAU)

ANOVA $^{\text {b }}$

\begin{tabular}{|l|r|r|r|r|r|}
\hline Model & Sum of Squares & df & Mean Square & F & \multicolumn{1}{c|}{ Sig. } \\
\hline $1 \quad$ Regression & 27.054 & 3 & 9.018 & 1.147 & $.341^{\mathrm{a}}$ \\
Residual & 346.030 & 44 & 7.864 & & \\
Total & 373.085 & 47 & & & \\
\hline
\end{tabular}

a. Predictors: (Constant), Density.MAU, Density.SPM, Density.MP

b. Dependent Variable: SLM2

\section{Hypothesis decision}

Discussion of the results of the test statistics above can be drawn from the decision of the hypothesis that the effect of motor vehicle density on noise pollution is very small and there is no significant influence or relationship between motor vehicle density on noise pollution that occurs on SLM2 on the third day.

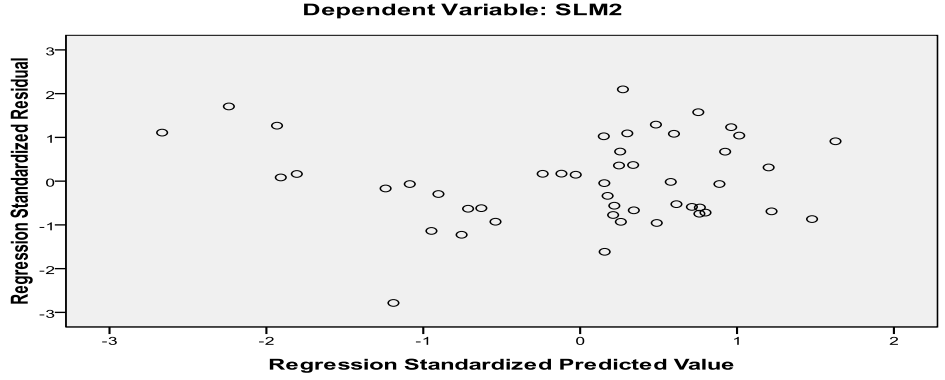

Figure 10. Distribution of the SLM2 Scatterplot test for motorcycle density (SPM), private car density (MP) and public passenger car density (MAU).

\section{Discussion of SLM3}

Analysis distance of $15.00 \mathrm{~m}$ from the edge of the highway $\mathrm{y}=78.821+0.006 \times 1-0.020 \times 2$ $0.066 \times 3$.

\section{Test Criteria}

Discussion of testing the summary model obtained by the value of $R=0.208$ which means that $x 1, x 2$ and $x 3$ have an effect of $20.80 \%$ on $y$.

Table 21. ANOVA Test Results on SLM3 for motorcycle density (SPM), private car density (MP) and public passenger car density (MAU)

\section{ANOVA $^{\text {b }}$}

\begin{tabular}{|ll|r|r|r|r|r|}
\hline \multicolumn{1}{|l|}{} & Sodel of Squares & df & Mean Square & F & \multicolumn{1}{c|}{ Sig. } \\
\hline 1 & Regression & 19.581 & 3 & 6.527 & .660 & $.581^{\mathrm{a}}$ \\
& Residual & 435.084 & 44 & 9.888 & & \\
Total & 454.665 & 47 & & & \\
\hline
\end{tabular}

a. Predictors: (Constant), Density.MAU, Density.SPM, Density.MP

b. Dependent Variable: SLM3 
Hypothesis decision

Discussion of the results of the test statistics above can be drawn from the decision of the hypothesis that the effect of motor vehicle density on noise pollution is very small and there is no significant influence or relationship between motor vehicle density on noise pollution that occurs on SLM3 on the third day.

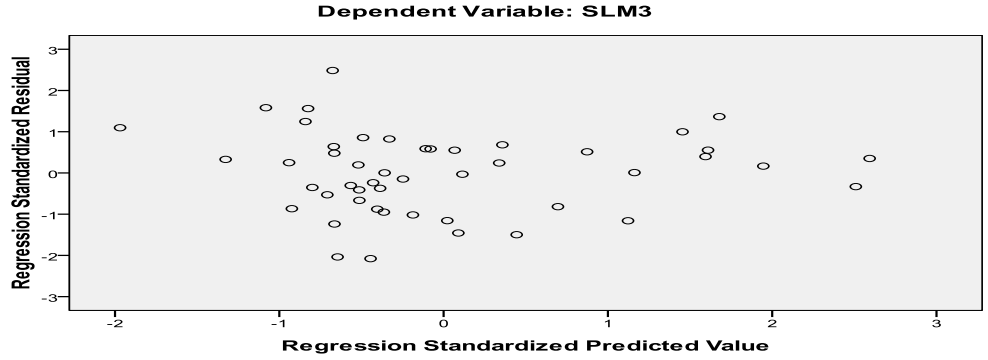

Figure 11. Spread of the SLM3 Scatterplot test for motorcycle density (SPM), private car density (MP) and public passenger car density (MAU)

\section{Discussion of Statistical Analysis on Saturday/March 01, 2014.}

Discussion of SLM1 analysis distance of $0,00 \mathrm{~m}$ from the edge of the highway $\mathrm{y}=92,172$ $-0,013 \times 1-0,054 \times 2-0,150 \times 3$.

\section{Test Criteria}

Discussion of testing the summary model obtained by the value of $R=0.407$ which means that $x 1, x 2$ and $x 3$ have an effect of $40.70 \%$ on $y$.

Table 22. ANOVA Test Results on SLM1 for motorcycle density (SPM), private car density (MP) and public passenger car density (MAU)

\begin{tabular}{|l|r|r|r|r|r|}
\hline \multicolumn{1}{|c|}{ ANOVA $^{\mathrm{b}}$} \\
\hline 1 Model & Sum of Squares & df & Mean Square & F & \multicolumn{1}{c|}{ Sig. } \\
\hline 1 Regression & 243.941 & 3 & 81.314 & 2.915 & .045 \\
Residual & 1227.585 & 44 & 27.900 & & \\
Total & 1471.526 & 47 & & & \\
\hline
\end{tabular}

a. Predictors: (Constant), Density.MAU, Density.SPM, Density.MP

b. Dependent Variable: SLM1

\section{Hypothesis decision}

The results of the test statistics above can be drawn from the decision of the hypothesis that the effect of motor vehicle density on noise pollution is very small and there is no significant influence or relationship between motor vehicle density on noise pollution that occurs on SLM1 on the fourth day. 


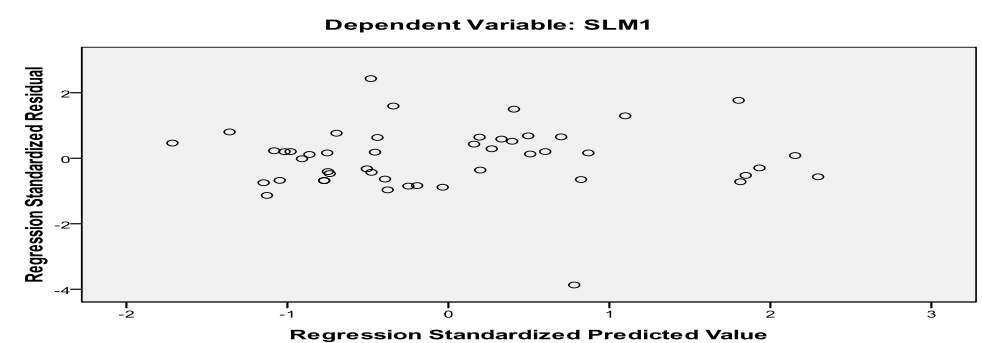

Figure 12. Distribution of the SLM1 Scatterplot test for motorcycle density (SPM), private car density (MP) and passenger public transport car density (MAU).

\section{Discussion of SLM2} $-0.059 \times 3$.

Analysis distance of $3.00 \mathrm{~m}$ from the edge of the highway $\mathrm{y}=80.542+0.003 \times 1-0.038 \times 2$

\section{Test Criteria}

Discussion of testing the summary model obtained by the value of $R=0.447$ which means that $x 1, x 2$ and $x 3$ have an effect of $44.70 \%$ on $y$.

Table 23. ANOVA Test Results on SLM2 for motorcycle density (SPM), private car density (MP) and public passenger car density (MAU)

ANOVA $^{\mathrm{b}}$

\begin{tabular}{|c|c|c|c|c|c|c|}
\hline \multicolumn{2}{|c|}{ Model } & Sum of Squares & df & Mean Square & $\mathrm{F}$ & Sig. \\
\hline \multirow[t]{3}{*}{1} & Regression & 78.754 & 3 & 26.251 & 3.668 & $.019^{\mathrm{a}}$ \\
\hline & Residual & 314.884 & 44 & 7.156 & & \\
\hline & Total & 393.638 & 47 & & & \\
\hline
\end{tabular}

a. Predictors: (Constant), Density.MAU, Density.SPM, Density.MP

b. Dependent Variable: SLM1

\section{Hypothesis decision}

Discussion of the results of the test statistics above can be drawn from the decision of the hypothesis that the effect of motor vehicle density on noise pollution is very small and there is no significant influence or relationship between motor vehicle density on noise pollution that occurs on SLM2 on the fourth day.

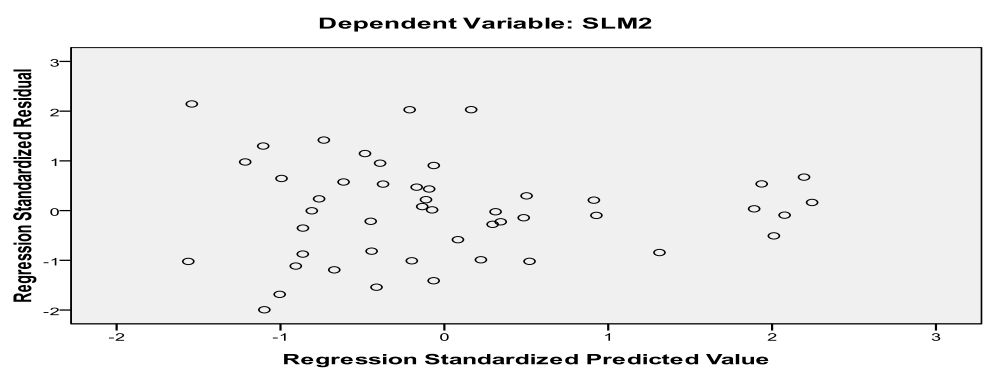

Figure 13. Deployment of the SLM2 Scatterplot test for motorcycle density (SPM), private car density (MP) and public passenger car density (MAU) 


\section{Discussion of SLM3}

Analysis distance of $15.00 \mathrm{~m}$ from the edge of the highway $\mathrm{y}=79.463+0.002 \times 1-0.034 \times 2$ $-0.110 \times 3$.

\section{Test Criteria}

Discussion of testing the summary model obtained by the value of $R=0.448$ which means that $x 3$ has an effect of $44.80 \%$ on $y$.

Table 24. ANOVA Test Results on SLM3 for motorcycle density (SPM), private car density (MP) and public passenger car density (MAU)

ANOVA $^{\mathrm{b}}$

\begin{tabular}{|l|r|r|r|r|r|}
\hline \multicolumn{1}{|l|}{ Model } & Sum of Squares & df & Mean Square & F & \multicolumn{1}{c|}{ Sig. } \\
\hline $1 \quad$ Regression & 82.372 & 3 & 27.457 & 3.688 & $.019^{\mathrm{a}}$ \\
Residual & 327.600 & 44 & 7.445 & & \\
Total & 409.973 & 47 & & & \\
\hline
\end{tabular}

a. Predictors: (Constant), Density.MAU, Density.SPM, Density.MP

b. Dependent Variable: SLM3

\section{Hypothesis decision}

Discussion of the results of the test statistics above can be drawn from the results of the hypothesis decision that the effect of motor vehicle density on noise pollution is very small and there is no significant influence or relationship between motor vehicle density on noise pollution that occurs on SLM3 on the fourth day.

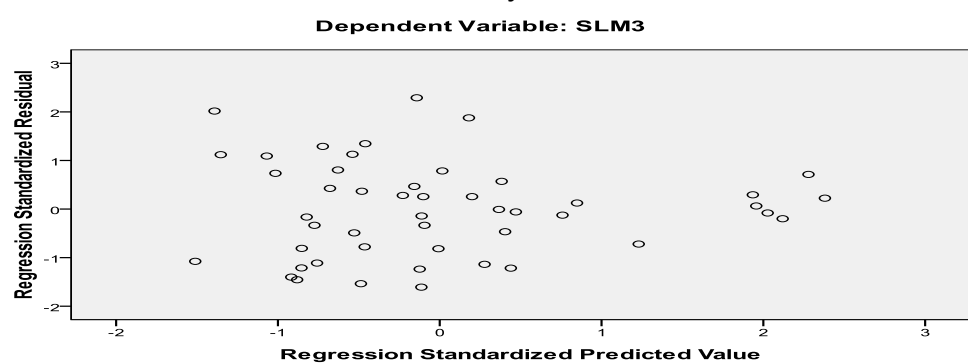

Figure 16. Deployment of the SLM3 Scatterplot test for motorcycle density (SPM), private car density (MP) and public passenger car density (MAU).

\section{CONCLUSION}

Motorcycle density and public transport car density have a significant effect on the noise pollution produced. The calculation and analysis obtained are on the equation with the first largest $R$ value on the second day of the third point (Sound Level Meter3), with a contribution of $50.50 \%$. as formulated in equation, $y=73.824+0.030 \times 1-0.020 \times 2-0.324 \times 3$. The meaning of this equation is that if there is no increase in motorcycle density and a decrease in the density of private cars and public transport cars, the level of noise pollution in SLM3 is $73.824 \mathrm{~dB}_{\mathrm{A}}$. However, if there is an increase in motorcycle density 0.030 and a decrease in the density of private cars and the density of public transport cars by 0.344 , the level of noise pollution will be reduced by $0.314 \mathrm{~dB}_{\mathrm{A}}$ in SLM3. The second largest $R$ value with motorcycle density, private car density and transport car density generally has a moderate effect on noise pollution in the second day of research at the point (Sound Level Meter2) with a contribution of $48.50 \%$. Obtained equation, $y=74,854+$ 
$0,024 \times 1-0,016 \times 2-0,191 \times 3$. This means that if there is no increase in motorcycle density and the density of public transport cars, the noise pollution level in SLM2 is $74,854 \mathrm{~dB}_{\mathrm{A}}$. However, if there is an increase in motorcycle density by 0.024 and a decrease in the density of private cars and public transport cars by 0.207 , there will be a decrease in the level of noise pollution by 0.183 $\mathrm{dB}_{\mathrm{A}}$ in SLM2.

\section{REFERENCES}

Buchari. 2007. Kebisingan Industri dan Hearing conservation,2007 USU Respository, Medan. Indonesian.

Departemen Pekerjaan Umum, 1997. Manual Kapasitas Jalan Indonesia (MKJI), Direktorat Jenderal Bina Marga, Jakarta. Pebruari 1997. (Indonesian)

Hidayati,Nurul. 2004. Pengaruh Arus Lalu Lintas Terhadap Kebisingan Studi Kasus Beberapa Zona Pendidikan Di Surakarta. Surakarta. (Indonesian)

Maudiawan Mubarak, Rulhendri Rulhendri, Syaiful Syaiful, 2020. Perencanaan Peningkatan Perkerasan Jalan Beton Pada Ruas Jalan Babakan Tengah Kabupaten Bogor, Astonjadro Jurnal Rekayasa Sipil, 9 (1), pp. 01-13. (Indonesian) http://ejournal.uika-bogor.ac.id/index.php/ASTONJADRO/article/view/2694

Menteri Negara Lingkungan Hidup. 1996. Buku Tingkat Kebisingan, Surat Keputusan Menteri Lingkungan Hidup Nomor: Kep-48/MENLH/1996/25 November 1996. Jakarta. (Indonesian)

Ofyar Z. Tamin, 2000. Perencanaan dan pemodelan transportasi, edisi ke dua, Penerbit ITB Bandung. (Indonesian)

Suwardjoko P. Warpani, 2002. Pengelolaan Lalu lintas dan Angkutan Jalan, Penerbit ITB Bandung. (Indonesian)

Syaiful, Syaiful. 2017, Engineering model of traffic and transportation safety with pattern of cooperation between sustainable region in Bogor, MATEC Web Conf., 138 (2017) 07008 DOI: https://doi.org/10.1051/matecconf/201713807008

Syaiful Syaiful, Mikhael Yuliantino, 2017. THE STUDY OF LAND PARKING MALL BOGOR INDAH PLAZA Proceedings of the Conference on Global Research on Sustainable Transport (GROST 2017) ISSN: 2352-5401, volume: 147 ISBN 978-94-6252-449-1 doi:10.2991/grost-17.2018.25 p. 286-303 https://www.atlantispress.com/proceedings/grost-17/25889389

Syaiful Syaiful, Doni Hariyadi. 2019, Case Study on Sustainable T-Jungtion Cibinong City Mall (CCM) in Bogor Indonesia. ARPN Journal of Engineering and Applied Science. 14(17): 2960-2971. http://www.arpnjournals.org/jeas/research papers/rp 2019/jeas 0919 7895.pdf

Syaiful Syaiful, Yogi Pratama. 2019, Sustainable Studies about General Public Transport Performance in the City of Bogor. ARPN Journal of Engineering and Applied Science.14(18):3241-3247.

http://www.arpnjournals.org/jeas/research_papers/rp 2019/jeas 0919 7925.pdf

Syaiful Syaiful, Sri Wiwoho Mudjanarko, 2019, Noise of Motor Vehicles at from of Baiturrahman Great Mosque Semarang City, The Spirit Of Society Journal, 2 (2) March 2019. 
https://jurnal.narotama.ac.id/index.php/scj/article/view/902

Syaiful Syaiful, 2020, Analysis on the Addition of Fiber the Strong Bending Mixed Concrete, ARPN Journal of Engineering and Applied Science. 15(6): 724-729.

http://www.arpnjournals.org/jeas/research papers/rp 2020/jeas 0320 8152.pdf

Syaiful Syaiful and Lian Lasmana, 2020, Study about level of railway road damage railways with sustainable PCI method, ARPN Journal of Engineering and Applied Science. 15(8): 962968.

http://www.arpnjournals.org/jeas/research papers/rp 2020/jeas 0420 8184.pdf

Triyanto, Syaiful, Rulhendri, 2019. Evaluasi Tingkat Kerusakan Jalan Pada Lapis Permukaan Ruas Jalan Tegar Beriman Kabupaten Bogor, ASTONJADRO Jurnal Rekayasa Sipil, 8(2),pp.70-79. (Indonesian)

http://ejournal.uika-bogor.ac.id/index.php/ASTONJADRO/article/view/2628

(C) 2020 by the authors. Submitted for possible open access publication under the terms and conditions of the Creative Commons Attribution (CC BY SA) license (https://creativecommons.org/licenses/by-sa/3.0/). 